\title{
The psychometric relationship between career thinking and salutogenic functioning amongst unemployed adults
}

\begin{tabular}{|c|}
\hline $\begin{array}{l}\text { Authors: } \\
\text { Kirk Austin }{ }^{1} \\
\text { Frans Cilliers }\end{array}$ \\
\hline $\begin{array}{l}\text { Affiliations: } \\
{ }^{1} \text { Department of Industrial } \\
\text { and Organisational } \\
\text { Psychology, University of } \\
\text { South Africa, South Africa }\end{array}$ \\
\hline $\begin{array}{l}\text { Correspondence to: } \\
\text { Frans Cilliers }\end{array}$ \\
\hline $\begin{array}{l}\text { Email: } \\
\text { cillifvn@unisa.ac.za }\end{array}$ \\
\hline $\begin{array}{l}\text { Postal address: } \\
\text { PO Box 392, Unisa 0003, } \\
\text { South Africa }\end{array}$ \\
\hline $\begin{array}{l}\text { Dates: } \\
\text { Received: } 13 \text { Feb. } 2011 \\
\text { Accepted: } 03 \text { Aug. } 2011 \\
\text { Published: } 10 \text { Nov. } 2011\end{array}$ \\
\hline $\begin{array}{l}\text { How to cite this article: } \\
\text { Austin, K., \& Cilliers, F. } \\
\text { (2011). The psychometric } \\
\text { relationship between career } \\
\text { thinking and salutogenic } \\
\text { functioning amongst } \\
\text { unemployed adults. } \\
\text { SA Journal of Industrial } \\
\text { Psychology/SA Tydskrif vir } \\
\text { Bedryfsielkunde, 37(1), Art. } \\
\text { 969, } 11 \text { pages. http://dx.doi. } \\
\text { org/10.4102/sajip.v37i1.969 }\end{array}$ \\
\hline
\end{tabular}

(C) 2011. The Authors. Licensee: AOSIS OpenJournals. This work is licensed under the Creative Commons Attribution License.
Orientation: Corporate survival mechanisms, like mergers, downsizing, restructuring and outsourcing, contribute to unemployment levels amongst adults. Psychological maturity seems to influence the quality of the career decisions that people make in these difficult circumstances. However, we do not know what their behavioural strengths are.

Research objectives: The objective of this study was to investigate the psychometric relationship between career thinking (negative and positive career thoughts) and salutogenic functioning (locus of control and sense of coherence) amongst unemployed adults.

Motivation for study: Career decision research has consistently surveyed students to understand career indecision. Adults are not a homogenous group. Therefore, this trend may not reflect throughout the larger adult population. For this reason, the researchers conducted exploratory research into the nature of career indecision amongst non-student adults.

Research design, approach and method: The researchers used a quantitative design that included a four-instrument survey on a purposive sample of 225 Canadian unemployed and non-student adults who had not decided on a career. They calculated correlations and regressions.

Main findings: The researchers reported significant relationships between the four constructs. They found that a sense of coherence predicted career thinking.

Contribution/value-add: A sense of coherence, which includes comprehension, meaningfulness and manageability, acts as a facilitator of effective career thinking.

Practical/managerial implications: During career assessment and guidance, the role of sense of coherence as a strength factor will indicate the person's readiness to make important career decisions.

\section{Introduction}

\section{Key focus of the study}

During stressful periods of unemployment, adults must make important decisions about their futures. Negative career thoughts impair effective career decisions whilst positive career thoughts facilitate decisions that have better direction.

\begin{abstract}
Much of the current literature on career indecision uses university populations and young adults as its basis. It is also apparent that young adults may face differing developmental stages and roles than older adults do.
\end{abstract}

These developmental differences may affect career decision-making in unique ways, depending on the nature of the sample. Therefore, the focus of this study was to expand the career choice literature by exploring the career indecision problems of older, non-student and adult populations using community-based research. University populations and young adults have recommended this approach. However, it has not come into effect (see Austin, Wagner \& Dahl, 2003; 2004; Dahl, 2010; Dahl, Austin \& Wagner 2010; Sampson, Peterson, Lenz, Reardon \& Saunders, 1996b; Weinstein, Healy \& Ender, 2002).

Broadening the literature in this way would make research more representative of the larger adult population.

\section{Background to the study}

The literature has criticised research into career development for its exclusive use of student-based samples. However, a later generation of studies followed the suggestion that career decision- 
making research should use community-based research sites (Reed, Lenz, Reardon \& Leierer, 2000) and non-student adult subjects (Austin, Wagner \& Dahl, 2003; 2004; Luzzo, Funk \& Strang, 1996; Sampson, Peterson, Lenz, Reardon \& Saunders, 1996b) to explore career decisions. These studies helped us to understand the nature of career indecision amongst adults.

The literature suggests that the difference between making a negative or positive decision depends on the person's level of positive psychology constructs (Snyder \& Lopez, 2009) and specifically salutogenic functioning (see Cilliers \& Kossuth, 2004). However, it is not clear exactly how these salutogenic strengths operate in the field of careers.

Therefore, this research sought to clarify the psychometric relationships between career thinking, vis-à-vis negative career thoughts and career decision-making self-efficacy, as well as salutogenic functioning, vis-à-vis locus of control and sense of coherence. The implications of these findings will have value for career development practice and literature. Using this information, the researchers formulated the research problem: to determine whether there is a relationship between career thinking and salutogenic functioning. If there is, to determine whether the chosen salutogenic constructs act as facilitating strengths for effective decision-making.

The objective of this study was to investigate the psychometric relationships between career thinking (negative and positive career thoughts) and salutogenic functioning (locus of control and sense of coherence) amongst unemployed adults. Apart from ascertaining the psychometric relationships, this research also adds to the body of knowledge that is relevant to career decision-making (or lack thereof) amongst nonstudent adults.

\section{Trends from the literature}

The fact that the adult population is not a homogenous group influences the career decision-making process (Dahl, Austin \& Wagner, 2010). The difficulty with generalising collegebased career indecision to the larger adult population is relevant to the fundamental distinctions that demarcate the boundary between the career indecision of students and older non-student adults.

College students do not represent the norm for older adult or young adult behaviour. In the United States (US), approximately $75 \%$ of the student population complete high school (Desruisseaux, 1998) and only 50\% enrol in college. In the first year of college, $27 \%$ of all students drop out. Of the remaining students, only 55\% graduate with a degree. Canadian students do not fare much better. There is a $50 \%$ student attrition during college (Perry, 2003).

The researchers could not trace any similar data for South African groups. That career indecision is conceptualised within such a narrow band of the student population is problematic.
Task orientation also determines student-based career indecision. In particular, students' career tasks are primarily relevant to their academic roles. Therefore, they usually face academic competition, unfamiliar academic tasks, pressure to excel, new social environments and pressure related to success and failure (Perry, Hladkyj, Pekrun \& Pelletier, 2001). Making career decisions during this time may affect students who make premature career choices (they need more information, need to avoid conflict, and others) or who are undecided (they defer choice, face developmental issues, and others) (Sampson, Reardon, Peterson \& Lenz, 2004).

Conversely, career decision-making for older adults often occurs during transitional periods like organisational mergers, downsizing, restructuring and outsourcing (Neault, 2002; Osberg, Wein \& Grude, 1995; Peterson \& González, 2005; Rothmann \& Coetzee, 2003). We see a similar tendency during high levels of unemployment (Amundson \& Borgan, 1996; Dahl, Austin, Wagner \& Lukas, 2008; Osipow, 1999). In 2010, the unemployment rate in the United States of America (USA) was 9.3\%, the Canadian rate was $7.6 \%$ and the South African rate was 25\% (Austin, 2005).

Loss of work or transition during periods of crisis means rethinking one's career and life direction. It creates greater tension (Dahl, 2010; Joseph \& Greenberg, 2001; Muchinsky, 2006). Older, non-student adults may have spent a lifetime acquiring skills relevant to a profession. To change may mean acquiring a completely new set of skills. Organisational change, downsizing or rightsizing may mean loss of earnings, status, identity and meaning (Feather, 1997; Judge, Thoresen, Pucik \& Welbourne, 1999; Muchinsky, 2006; Osberg, Wien \& Grude, 1995). Making career decisions whilst unemployed causes high levels of stress for most adults (Dahl, 2010; Hanish, 1999; Starrin, Jönsson \& Rantakeisu, 2001; Vinokur \& Schul, 2002).

The stress-buffering factors of non-student adults may affect their career decisions during times of unemployment. Researchers have still to explore the career decision-making problems of this population extensively. In order to explore the nature of career indecision amongst non-student adults, the researchers proposed two domains for the research. These were career thinking and salutogenic functioning.

Career thinking refers to the positive and negative cognitions about career choice activities. In the career development literature, career thoughts have significantly influenced the career choice process (Kleiman, Gati, Peterson, Sampson, Reardon \& Lenz, 2004; Strauser, Lustig, Keim, Ketz \& Malesky, 2002). In particular, negative career thoughts have yielded significant relationships with career-related anxiety (Dahl, Austin, Wagner \& Lukas, 2008; Sampson, Reardon, Peterson \& Lenz, 2004), and this anxiety limits career development behaviour (Carr, 2004). In addition, negative career thoughts have been empirically linked to job-avoidance behaviour (Judge \& Locke, 1993), low skill confidence (Wright, 2001), academic indecision (Kilk, 1997) and poor employmentseeking activity (Keim, Strauser \& Ketz, 2002). 
In the career development literature, negative career thoughts link empirically to greater levels of perfectionism and career indecision (Osborn, 1998), depression and career indecision (Saunders, Peterson, Sampson \& Reardon, 2000), career indecision (Austin, Wagner \& Dahl, 2003; Kleiman, Gati, Peterson, Sampson, Reardon \& Lenz, 2004; Wright, 2001) and career indecisiveness (Austin, Wagner \& Dahl, 2004; Austin, Dahl, \& Wagner, 2010).

In the extant career development literature, positive career thoughts relate to the efficacy beliefs about one's ability about career choice activities. Higher levels of efficacy are associated with lower levels of stress, anxiety, perception of barriers and an increase in problem-solving appraisal (Bandura, 1999; 2000; Betz, 2004; Lent, Hackett \& Brown, 2000; Paa \& McWhirtner, 2000) and slower withdrawal from activities (Betz, 2004; Betz \& Luzzo, 1996; Mau, 2003). Persons with positive career self-efficacy beliefs also have greater levels of self-esteem and internal control beliefs (Brown, Reedy, Fountain, Johnson \& Dichiser, 2000; Paulsen \& Betz, 2004). In the career decision-making literature, people with greater positive career self-efficacy beliefs have fewer career decision-making problems (Betz, Klein \& Taylor, 1996) and maladaptive attributions (Betz, 2004). Furthermore, positive career decision-making self-efficacy beliefs link empirically to stronger career exploration plans and intentions (Ochs \& Roessler, 2004).

Career thinking is a contributor toward career indecision. In particular, career thinking, both positive and negative, empirically relates to and predicts career indecision (Austin, Wagner \& Dahl, 2003; 2004; Bergeron \& Romano, 1994; Reed, Lenz, Reardon \& Leirer, 2000; Saunders, Peterson, Sampson \& Reardon, 2000; Taylor \& Betz, 1983; Taylor \& Popma, 1990). Using career thinking would be valuable in exploratory research with non-student adults.

\section{Career thoughts}

Career decision-making is complex, interactive and produces stress (Lustig \& Strauser, 2008; Saunders, Peterson, Sampson $\&$ Reardon, 2000). Over the past century, career development researchers have suggested numerous factors that influence career choice. In recent years, the literature has sought to clarify the nature of career decision status. Further research has been suggested in order to clarify its boundaries (Gordon, 1998; Sampson, Reardon, Peterson \& Lenz, 2004).

Important to the literature on career indecision is the trend toward youth in research. Where career development research has explored the contribution of factors to making career decisions, it has sampled high school and college student populations extensively (Gordon, 1998; McWhirtner, Rasheed \& Crothers, 2000), leaving the career indecision of non-student adults virtually unexamined (Quimby \& O'Brien, 2004; Weinstein, Healy \& Ender, 2002). This may limit the generalisability of such research to older nonstudent adult populations. Researchers should explore the factors that influence the career decision making of older non-student adults further (Austin, Wagner \& Dahl, 2003; 2004; Dahl, Austin \& Wagner, 2010).

The career-development literature focuses on undergraduate student populations in their late teens and early twenties. The difficulty with this is that developmental factors influence making career decisions (Patton \& Creed, 2001; Peterson \& González, 2005; Sampson, Reardon, Peterson \& Lenz, 2004; Sharf, 2006). Therefore, developmentally mature adults (in interests, understanding, abilities and self-concept) move through distinct stages during their lives (Super, 1983). Undergraduate students, who are traditionally under the age of 25 , are engaged in tasks related to the 'exploration' stage of their career development. In contrast, older adults (25-44 years old) would be entering the 'establishment' stage of Super's model. Their task during this stage is to stabilise their career choices. They achieve this by using their skills and talents in work environments and by confirming that their career choices are suitable. Older adults (45 and older) would also have different developmental stages ('maintenance' or 'disengagement') and tasks to young adults (Super, 1990; Super, Savickas \& Super, 1996).

\section{Salutogenic functioning}

Salutogenic functioning has demonstrated its effects in mediating stress and promoting well-being and career agency (see Van der Colff \& Rothmann, 2009). For this reason, including it in non-student adult-based research would benefit the exploration of career indecision. Although numerous salutogenic factors have surfaced from the field of positive psychology, two factors are interesting to the present research. These are locus of control and sense of coherence (see Snyder \& Lopez, 2009; Strümpfer, 1990; 1995).

In the health-related literature, internal control expectancy has been associated with greater salutogenic functioning. In particular, internal control expectancy has been empirically associated with better health (Bobak, Pikhart, Hertzman, Rose \& Marmot, 1998), psychological well-being (Morrison, O'Connor \& Morrison, 2001; Turner, Barling \& Zacharatos, 2002), job satisfaction (Rothman \& Agathagelou, 2000) and effective stress mediation during unemployment (Litt, 1988; Waters \& Moore, 2002) as well as stress mediation in African men (Van Der Merwe \& Greef, 2003). In this same literature, external control is associated with poor psychological adjustment and coping (Hack \& Degner, 2004), avoidancerelated coping and decreased personal agency (Skinner, 1996; Thompson, 2002; Wanberg, 1997).

In student-based career development research, locus of control has an empirical link to career thinking and career indecision (Fuqua, Blum \& Hartman, 1988; Kerpelman \& Mosher, 2004; Larson, Piersel, Imao \& Allen, 1990; Luzzo, 1995; Osipow \& Reed, 1995; Saunders, Peterson, Sampson \& Reardon, 2000; Taylor, 1982; Taylor \& Popma, 1990; Weinstein, Healy \& Ender, 2002). Further career development research with a non-student population would improve the literature. 
Sense of coherence is also a salutogenic factor that has demonstrated stress-mediation and agency-promoting tendencies. Therefore, sense of coherence relates strongly to individual well being (Chamberlain, Petrie \& Azriah, 1992; Ryland \& Greenfield, 1991). It also mediates perceived stress significantly (Hedov, Annernen \& Wikblad, 2002; Hintermair, 2004; Kalimo, Pahkin \& Mutanen, 2002), predicts suicidal ideation (Rothman \& Van Rensberg, 2002), mediates hostility (Kivimaeki, Elovainio \& Vahtera, 2002), anxiety and depression (Edwards \& Besseling, 2001), life satisfaction and inter-role conflict (Diraz, Ortlepp \& Greyling, 2003) as well as burnout (Cilliers, 2002; 2003). In the salutogenic literature, sense of coherence also relates to other positive expectancy constructs like self-efficacy (Cilliers \& Kossuth, 2004; Rachman, 1990) and locus of control (Cilliers \& Kossuth, 2004; Lustig \& Strauser, 2008; Pallant \& Lae, 2002). In careerrelated research, sense of coherence has demonstrated stressmediating properties (Höge \& Bússing, 2004; Rothmann \& Coetzee, 2003). Seminal research has linked sense of coherence to negative career thinking (Lustig \& Strauser, 2002; 2008) and suggested that it relates significantly to, and predicts, dysfunctional career thoughts and career indecisiveness. It suggests further research using salutogenic factors.

\section{Research objective}

The objective of this study was to investigate the psychometric relationship between career thinking (negative and positive career thoughts) and salutogenic functioning (locus of control and sense of coherence) amongst unemployed adults.

\section{Potential value of the study}

If one can find significant relationships between the constructs, the role of sense of coherence, as a strength factor, could show people's readiness to make important career decisions. The article consists of the study's research approach and method. More specifically, the article covers the participants, measuring instruments, research procedure and statistical analysis.

The researchers presented the results using descriptive and inferential statistics and their acceptance of the research hypothesis. The in-depth discussion of the results culminated in the formulation of the conclusions, recommendations and the limitations of the study.

\section{Research design \\ Research approach}

The study followed a quantitative design within the positivistic research paradigm (Breverton \& Millward, 2004; Terre Blanche, Durrheim \& Painter, 2006). The researchers conducted a field survey and used primary data in a correlational approach to ascertain the psychometric relationships between the two chosen constructs: career thinking and salutogenic functioning.

\section{Research method \\ Research participants}

The target population was participants in an Englishspeaking Career Decision Making Programme (CDMP) presented at different sites in the greater Vancouver area (British Columbia, Canada), funded by the government of Canada. Unemployed, career undecided, non-student adults attended the programme.

Purposive sampling (Babbie, 2001; Terre Blanche et al., 2006) included 225 consenting participants in the 2005 programme. The sample consisted of 121 women (54\%) and 104 men $(46 \%)$. Their average age was 37.47. Their levels of education varied from high school or lower (65\%) to university level (35\%). The length of their unemployment varied between three months (53\%), four to six months (14\%) and longer than six months (33\%).

\section{Measuring instruments}

The researchers measured career thinking using the Career Thoughts Inventory (CTI) and The Career Decision Making Self Efficacy Scale- Short Form (CDMSE-SF). They measured salutogenic functioning using the I-E Locus of Control Scale (I-E LOCS) and the Orientation to Life Questionnaire (OLQ).

The Career Thoughts Inventory: The Career Thoughts Inventory (Sampson, Peterson, Lenz, Reardon \& Saunders, 1996a) measures negative career thoughts (dysfunctional thinking based on assumptions) attitudes, behaviours, beliefs, feelings and plans or strategies that influence and inhibit effective career decision-making (Sampson, Peterson, Lenz, Reardon \& Saunders, 1996b). The 48 4-point Likerttype items yield a total and three subscale scores. The total score is a single global indicator of dysfunctional thinking in career problem solving and decision-making (Sampson et al., 1996b). Its subscales measure Decision-making Confusion (DMC), Commitment Anxiety (CA) and External Conflict (EC).

DMC is the inability to initiate or sustain decision-making because of disabling emotions and/or a lack of understanding about making decisions itself. CA is the inability to make a commitment to a specific career choice, accompanied by generalised anxiety about the outcomes of making decisions, which perpetuates indecision. EC is the inability to balance the importance of one's own self-perceptions with the importance of input from others, resulting in a reluctance to assume responsibility for making decisions. The scores range from 0 to 144. A high score shows strong negative thinking, which inhibits making career decisions.

Internal consistency (alpha) coefficients for the CTI (Sampson, Peterson, Lenz, Reardon \& Saunders, 1999) range from 0.97 to 0.93 for all norm groups and 0.97 for adults. Alpha coefficients for the subscales range between 0.94 (DMC), 0.91(CA) and 0.81 (EC). Test-retest reliability over four weeks, with high school and college samples only, gave a stability coefficient for the total score of $r=0.86$. The combined college and high 
school stability coefficients for the construct scales measured 0.77 (CTI total), 0.77(DMC), 0.75 (CA) and 0.63 (EC), showing adequate stability (Sampson et al., 1999). The researchers determined convergent validity of the CTI against the career decision-making instruments that follow:

- My Vocational Situation (Holland, Daiger \& Power, 1980)

- Career Decision Scale (Osipow, Carney, Winer, Yanico \& Koschier, 1976)

- Career Decision Profile (Jones, 1989)

- Revised NEO Personality Inventory (Costa \& McCrae, 1992).

The conclusion the researchers made was that, for adults, the CTI scales had consistent inverse correlations with comfort, choice, decidedness and lack of information need and had a positive correlation with anxiety (Sampson, Peterson, Lenz, Reardon \& Saunders, 1999).

The Career Decision Making Self Efficacy Scale - Short Form: The Career Decision Making Self Efficacy Scale - Short Form (Betz \& Taylor, 1994) measures positive career thoughts, described as self-efficacy beliefs related to career choice competencies. The 25 items yield a total. Item responses range in ascending order from 0 (indicating no confidence) to 9 (indicating complete confidence in the specific task). Scores range from 0 to 225. A high score indicates career decisionmaking self-efficacy, defined as 'the degree of belief that he/ she can successfully complete tasks necessary to make career decisions' (Betz \& Taylor, 1994, p.8). The CDMSE Short Form version is a reliable 'global measure' of the construct (Betz \& Luzzo, 1996; Luzzo, 1996). The alpha coefficient for the CDMSE-SF total score was 0.94 (Betz, Klein \& Taylor, 1996), whilst test-retest reliability over six weeks yielded a value of 0.83 (Luzzo, 1993).

Research on other career development constructs has supported concurrent validity empirically through career indecision (Betz \& Luzzo, 1996), career choice certainty (-0.68) and career indecision $(-0.63)$ - both measured using the Career Decision Scale - and with the My Vocational Identity Scale (0.63). The conclusion the researchers reached was that the CDMSE-SF is a psychometrically sound measure of career decision-making self-efficacy for application in research and counselling (Betz, Klein \& Taylor, 1996).

The I-E Locus of Control Scale: The I-E Locus of Control Scale (Rotter, 1966) measures locus of control. It is the cognitive expectancy in areas related to personal control (achievement, dominance and affiliation). The 29 items have a forced choice structure (' $a$ ' or ' $b$ '). One adds them to yield a total score for locus of control along a one-dimensional continuum (except for five filler items that one excludes from the summing procedure). Scores range from 0 to 23 . A high score indicates external locus of control and a low score internal locus of control.

Many researchers have confirmed internal consistency and test-retest reliability over many years (see Auxier, 1994; Cilliers \& Kossuth, 2004; Fournier \& Jeanrie, 2003).
Specifically, researchers reported alpha coefficients of between 0.62 and 0.79 (see Antonovsky, 1987; De Brabander, Hellemans \& Boone, 1999; Friedman, Schwartz, Schnall, Landsbergis, Pieper, Gerin \& Pickering, 2001; Latiff, 2000; Rotter, 1966) and test-retest reliability of between 0.49 and 0.83 (Taylor \& Popma, 1990). Researchers have reported concurrent validity with a broad array of other psychological constructs and instruments. These were:

- the Cognitive Style Inventory (cooperative -0.18) (Van Den Broek, Vanderheyden, \& Cools, 2003)

- the Myers-Briggs Type Indicator (MBTI) (0.22)(Van Den Broek, Vanderheyden, \& Cools, 2003)

- need for cognition (-0.64) (Patrick \& Durndell, 2004)

- the Vocational Locus of Control Scale (-0.40) (Fournier, Jeanrie \& Drapeau, 1996)

- the Internality (-0.41), Powerful Others (0.25) and Chance (0.56) Scales(Levenson, 1981)

- the Work Locus of Control Scale (0.38-0.54)(Spector, 1988).

In terms of salutogenic functioning, the I-E LOCS has yielded convergent validity of 0.39 with the orientation to life scale that measures Antonovsky's sense of coherence construct (Rumbaut, Anderson \& Kaplan, 1983).

The Orientation to Life Questionnaire: The Orientation to Life Questionnaire (Antonovsky, 1979) measures sense of coherence, which is the global degree to which a person has a pervasive, enduring and dynamic feeling of confidence that:

- stimuli are structured, predictable and explicable

- one has the resources to meet the demands the stimuli posed

- these encounters are worthy of investment and confrontation (Antonovsky, 1987).

The 29 7-point items yield a total and three subscale scores for comprehensibility, manageability and meaningfulness. According to Antonovsky (Antonovsky, 1998; Korotkov, 1998), the subscales are theoretically and empirically inseparable: factor analysis yielded a single latent factor (see Antonovsky, 1993; Frenz, Carey \& Jorgensen, 1993; Korotkov, 1998). Scores range from 29 to 203 and represent a single global measure of sense of coherence. A high score indicates a strong sense of coherence. Internal consistency for the OLQ has ranged from an average of 0.91 for published articles, 0.85 for theses and dissertations and 0.88 for unpublished studies (Antonovsky, 1993).

Research in career decision-making literature indicated that the alpha coefficient for the OLQ was 0.91 (Lustig \& Strauser, 2002). Researchers have confirmed test-retest stability for between one and four weeks as between 0.92 and 0.93 (Frenz, Carey \& Jorgensen, 1993) and 0.54 after two years (Felton, 1996). More specifically, the test-retest stability for Dutch students was 0.80 after six weeks and for Afrikaans-speaking farmers it was 0.97 after five weeks. Adults had an average age of 55 in the USA (0.80)(Antonovsky, 1993).

Researchers have established convergent validity with different constructs like: 
- $\operatorname{anxiety}(-0.69,-0.50,-0.85,-0.85$ and 0.75) (Antonovsky, 1993; Flannery, Perry, Penk \& Flannery, 1994; Frenz, 1990; Frenz, Carey \& Jorgensen, 1993; Hart, Hittner \& Paras, 1991)

- depression (-0.60) (Frenz, 1990; Frenz, Carey \& Jorgensen, 1993)

- well being $(0.40,0.48)$ (Antonovsky, 1993; Harris, 1997)

- self-efficacy (0.57, 0.50) (Felton, 1996; Frenz, Carey \& Jorgensen, 1993)

- negative affectivity (-0.61)(Höge \& Büssing, 2004; Johnson, 2004)

- tension (-0.33)(Rothmann \& Coetzee, 2003)

- strain (-0.61) (Höge \& Bússing, 2004)

- perceived stress (-0.67, -0.27, -0.73)(Antonovsky, 1993; Flannery, Perry, Penk \& Flannery, 1994; Frenz, Carey \& Jorgensen, 1993)

- $\quad$ work stress (-0.34) (Höge \& Bússing, 2004)

- internal LOC $(0.40,0.48,0.55)$ (Antonovsky, 1993; Flannery, Perry, Penk \& Flannery, 1994; Johnson, 2004)

- life interest (0.37) (Frenz, Carey \& Jorgensen, 1993)

- dysfunctional career thinking (-0.35) (Lustig \& Strauser, 2002; 2008).

\section{Research procedure}

At the beginning of each CDMP, the researchers invited participants to participate in the locus of control research project, which was separate from their CDMP participation. The first author enlisted research assistants (RAs) from each site and trained then on the specific research administration procedures. The first author gave limited information to the RAs to prevent experimenter bias (Babbie, 2001; Terre Blanche et al., 2006).

The researchers distributed the research forms before introducing any career decision-making interventions to control for treatment effects. All participants would complete all the assessments before the CDMP could influence their career thinking, level of unemployment stress or salutogenic functioning. The RAs gave envelopes to consenting participants. They contained brief instructions accompanied by a consent form, CTI, CDMSE-SF, I-E LOC and OLQ for them to complete. The RAs collected and sealed the completed forms in the envelopes for collection and analysis by the first author. The ethical considerations (Babbie, 2001; Terre Blanche et al., 2006) consisted of ensuring participants' voluntary consent.

\section{Statistical analysis}

The researchers computed Pearson product-moment correlations to determine the relationship between the constructs of career thinking, salutogenic functioning and hierarchical multiple-regression analyses to establish the predictive value of the constructs. The researchers used career thinking as the independent variable and salutogenic functioning as the dependent variable. They used locus of control and sense of coherence independently and regressed on negative career thinking and career decision-making selfefficacy.
The researchers performed statistical power analysis to reduce the risk of Type 1 and Type 2 errors. They used Cohen's (1992) guidelines that 85 pairs of scores are suitable for correlational analysis for a 0.30 (medium) effect size at $80 \%$ power. In this analysis, the researchers accepted the current sample $(N=225)$ to guarantee adequate power. They followed Cohen's (1992) suggestion that a sample size of 126 was suitable for multiple regression using five independent variables. It would include a power of 0.80 , a medium effect size (0.15) and a significance of $\alpha=0.01$. They implemented Cohen's (1992) suggestion of $f^{2}=0.35$ to indicate a large effect size.

Using their research problem and in view of the statistical analysis they chose, the researchers formulated the research hypothesis that there is a significant relationship between career thinking and salutogenic functioning.

\section{Results \\ Descriptive statistics and instrument reliability}

Table 1 below contains the descriptive statistics (means and standard deviations) of career thinking (CTI and CDMSE$\mathrm{SF}$ ) and salutogenic functioning (I-E LOCS and OLQ). The reliability of all four instruments was acceptable. The alpha coefficients for the CTI and CDMSE-SF were $\alpha=0.90$ and $\alpha=0.95$ respectively. These were consistent with the literature (Betz, Klein \& Taylor, 1996; Sampson, Peterson, Lenz, Reardon \& Saunders, 1996b). The alpha coefficients for the I-E LOCS and OLQ were $\alpha=0.74$ and $\alpha=0.85$ respectively. These were consistent with those the literature reported (Antonovsky, 1987; 1993; De Brabander, Hellemans \& Boone, 1999; Friedman, Schwartz, Schnall, Landsbergis, Pieper, Gerin \& Pickering, 2001; Latiff, 2000; Lustig \& Strauser, 2002; Rotter, 1966).

\section{Inferential statistics}

The table contains the correlations between CTI, CDMSESF, I-E LOCS and OLQ. All correlations were significant at $p<0.01$. Therefore, the researchers accepted the research hypothesis that there is a significant relationship between career thinking and salutogenic functioning. The regression analysis showed that the I-E LOCS did not, and that the OLQ did, predict the CTI and the CDMSE-SF significantly.

The I-E LOCS had a significant correlation with the CTI $(r=0.349, p<0.01)$ and the CDMSE-SF $(r=-0.307, p<0.01)$. Nevertheless, locus of control accounted for only $1 \%$ of unique variance $\left(R^{2} \Delta=0.01, p>0.01\right)$ in the criterion measure, $F(1,222)=4.15, p>0.01$ for the CTI, $0.3 \%$ unique variance $\left(R^{2} \Delta=0.003, p>0.01\right)$ in the criterion measure and $F(1,224)=1.05, p>0.01$ for the CDMSE-SF. According to Cohen's (1992) suggestion, the I-E LOCS showed no significance for the CTI $\left(f^{2}=0.01\right.$ and a very low significance for the CDMSE-SF $\left(f^{2}=0.003\right)$.

The OLQ maintained a significant correlation $(r=-0.625$, $p<0.01)$ with the CTI and accounted for $28 \%\left(R^{2} \Delta=0.28\right.$, 
TABLE 1: Descriptive and inferential statistics $(N=225)$.

\begin{tabular}{|c|c|c|c|c|c|c|c|c|c|c|}
\hline \multicolumn{2}{|c|}{ Variable } & \multicolumn{2}{|c|}{ Descriptive statistics } & \multicolumn{7}{|c|}{ Inferential statistics: correlations } \\
\hline No. & Instrument & Mean & SD & 1 & 2 & 3 & 4 & 5 & 6 & 7 \\
\hline 1 & CTI (total) & 49.81 & 20.560 & - & - & - & - & - & - & - \\
\hline 2 & $\mathrm{DCM}$ & 11.85 & 7.233 & 0.89 & - & - & - & - & - & - \\
\hline 3 & CA & 13.71 & 5.162 & 0.81 & 0.72 & - & - & - & - & - \\
\hline 4 & EC & 4.79 & 3.045 & 0.68 & 0.51 & 0.49 & - & - & - & - \\
\hline 5 & CDMSE-SF & 158.34 & 34.590 & -0.57 & -0.58 & -0.42 & -0.31 & - & - & - \\
\hline 6 & I-E LOCS & 9.28 & 4.080 & 0.34 & 0.29 & 0.23 & 0.28 & -0.30 & - & - \\
\hline 7 & OLQ & 131.92 & 24.970 & -0.62 & -0.59 & -0.51 & -0.42 & 0.55 & -0.40 & - \\
\hline
\end{tabular}

Note: all correlations were significant at $p<0.01$.

SD, standard deviation; DCM, decision-making confusion; CA, commitment anxiety; EC, external conflict; CDMSE-SF, career decision-making self-efficacy; I-E LOCS, Internal-External Locus of Contro Scale; OLQ, Orientation to Life Questionnaire.

$p<0.001)$ of the variance in negative career thinking, $F(1,222)$ $=103.9, p<0.001$. According to Cohen's (1992) suggestion, the effect size of $f^{2}=0.39$ indicated practical significance.

The OLQ maintained a significant correlation $(r=0.552$, $p<0.01)$ with the CDMSE-SF and accounted for $29.8 \%$ $\left(R^{2} \Delta=0.298, p<0.001\right)$ of the variance in career decisionmaking self-efficacy, $F(1,224)=103.76, p<0.001$. According to Cohen's (1992) suggestion, the effect size of $f^{2}=0.42$ showed a large practical significance.

\section{Discussion}

The objective of this study was to investigate the psychometric relationships between career thinking (negative and positive career thoughts) and salutogenic functioning (locus of control and sense of coherence) amongst unemployed adults. The researchers investigated whether high levels of salutogenic functioning will positively facilitate positive career thinking. The researchers found a significant negative relationship between negative career thoughts and career decisionmaking self-efficacy. This result refutes the doubts the literature expressed (see Sampson, Peterson, Lenz, Reardon \& Saunders, 1996b).

The researchers found a significant relationship between career thinking, vis-à-vis negative career thoughts and career decision-making self-efficacy and locus of control. This result confirmed earlier career development research (Luzzo, 1995; Saunders, Peterson, Sampson \& Reardon, 2000; Taylor \& Popma, 1990). In behavioural terms, people who show internal locus of control are more likely to maintain more functional career thinking and greater confidence in their ability to make career decisions. In addition, people who can appraise personal control better are also less confused about their career choices, are less anxious about their career choice commitment and show less conflict about external factors.

The researchers found a significant relationship between career thinking, vis-à-vis negative career thoughts, career decision-making self-efficacy and sense of coherence. This result confirmed earlier career development research and added to its depth (Lustig \& Strauser, 2002; 2008). In behavioural terms, people with a greater sense of coherence showed more functional career thinking and greater confidence about career decision-making tasks. In addition, a greater sense of coherence corresponded to less confusion about making career decisions, less anxiety about career choice commitment and less conflict about external factors. The result is consistent with the evidence in salutogenic literature, where low levels of a sense of coherence relate significantly to cognitive distortions (Kalimo \& Vuori, 1990), dysfunctional thinking (Karlson, Seger, Osterberg, Gunnel \& Orbaek, 2000) and high levels of anxiety (McSherry \& Holm, 1994).

The results showed that a sense of coherence significantly predicted career thinking, vis-à-vis negative career thoughts and career decision-making self-efficacy. This finding is consistent with salutogenic and career research based on the strong negative relationship between a sense of coherence and dysfunctional thinking (Karlson, Seger, Osterberg, Gunnel \& Orbaek, 2000; Lustig \& Strauser, 2002; 2008).

Locus of control did not predict career thinking behaviour. This is consistent with results that described its 'poor predictive value' (Flannery, Perry, Penk \& Flannery, 1994; Luzzo, 1995). In behavioural terms, people with a greater sense of coherence are more likely to exhibit less negative career thinking in general, less confusion about their career choices, less anxiety about committing to a choice and less conflict because of external factors. In addition, these people would also have greater confidence about undertaking career decision-making tasks (based on the result that both negative and positive career thoughts contribute to career agency and decision status).

The literature emphasises that adults are becoming increasingly uncertain about their career choices and frequently make their career decisions whilst unemployed (Bandura, 1997; Dahl, 2010). We also know that non-student adults face unique stress and anxiety about unemployment (Hanish, 1999; Joseph \& Greenberg, 2001; Starrin, Jönsson \& Rantakeisu, 2001) and that this limits their career choices.

This study suggested that a sense of coherence, as a salutogenic strength, acts as a mitigating factor when coping with the stress of unemployment. The results suggest that higher levels of a sense of coherence reflect people's pervasive and enduring confidence that the nature of unemployment and career decision-making is structured, explicable and predictable; that they have resources to meet the demands of unemployment and career decision-making; and that they should encounter and confront these issues. Therefore, one 
can see that a sense of coherence is a 'career specific' factor that influences career choice. Future research that uses sense of coherence (SOC) could help us understand the nature of career indecision in non-student adults (Savickas, 2001; Vinokur \& Schul, 2002).

With regard to the literature on career decision status, research has suggested that career thinking relates strongly to career indecision. In particular, negative career thoughts are significantly related to, and predictive of, career indecision (Austin, Wagner \& Dahl, 2003; 2004; Reed, Lenz, Reardon \& Leirer, 2000; Saunders, Peterson, Sampson \& Reardon, 2000).

Furthermore, research has shown that career decisionmaking self-efficacy relates significantly to, and predicts, career indecision (Bergeron \& Romano, 1994; Taylor \& Betz, 1983; Taylor \& Popma, 1990) and that a sense of coherence relates empirically to, and predicts, negative career thinking and career decision-making self-efficacy. It makes intuitive sense because it also contributes to or predicts career decision status. Future research should use the SOC to explore career decidedness taxonomies (Gordon, 1998; Sampson, Reardon, Peterson \& Lenz, 2004)

As a sense of coherence emerges from the larger field of positive psychology, other factors may have value for career development research. In particular, emotion-focused constructs like emotional intelligence, positive affectivity, emotional coping and meaning could all contribute effectively to mediating stressors that relate to unemployment and career choice. Researchers have conducted seminal research to achieve this (Dahl, Austin, Wagner \& Lukas, 2008). In addition, cognitive-focused constructs like mindfulness, signature strengths, hope and creativity could contribute to understanding the interaction between managing stress and making career decisions. Future research, which uses these constructs, could add to the literature about adult-orientated stress management and career choice.

\section{Conclusions}

The researchers concluded that there is a significant psychometric relationship between career thinking (negative and positive career thoughts) and salutogenic functioning (locus of control and sense of coherence) amongst unemployed adults. They also concluded that a sense of coherence acts as a facilitator of effective career thinking: the higher the person's functioning on comprehension, meaningfulness and manageability as salutogenic characteristics, the easier it will be for that person to make decisions leading to positive career outcomes.

\section{Implications of the research and recommendations}

The research has implications for career development practitioners. In particular, if they use the SOC as a screening instrument it could reveal practical distinctions in adult populations. Companies preparing to downsize could evaluate which affected personnel might require extra support upon termination. The research suggest that people with lower levels of salutogenic functioning will require more support to mediate stress and plan their careers.

In addition, career development personnel, who assist adults with career transition and planning, could find the SOC useful as an intake measure. In particular, adults who are high in salutogenic functioning may require less support, or make career decisions more efficiently, than those with lower salutogenic functioning. Future research should examine this thesis.

\section{Limitations of the study and suggestions}

This study had limitations in terms of its empirical design. Career literature suggests that adults are not homogenous in their career thinking and career decision-making (Dahl, Austin \& Wagner, 2010; Savickas, 1994) and that developmental factors affect career indecision (Patton \& Creed, 2001; Super, Savickas \& Super, 1996). This study did not use the participants' age-related life stage (Super, 1990) as a criterion for sampling. Although the mean age was 37.47 , roughly $10 \%$ of participants were under the age of 24 and fell within the exploration life stage that Super's model describes. The uncertainty and related behaviours typical of this stage could have influenced the results. The researchers suggest that future research differentiates heterogeneity in terms of career stages.

A further limitation was the single cohort model the researchers used. The researchers framed the length of unemployment as up to three months, four to six months and more than six months. This became a single continuum of between 0 and 111 months. Including more and discrete groupings may have excluded important information. This argument uses evidence from the literature about how unemployment facilitates high levels of stress, anxiety, worry and threats to esteem (see Hanish, 1999; Joseph \& Greenberg, 2001; Starrin, Jönsson \& Rantakeisu, 2001) and how longterm unemployment increases depressive characteristics and decreases the chances of re-employment (Vinokur \& Schul, 2002). This study failed to establish whether longterm unemployment contributes to reduced career decisionmaking efficacy and salutogenic functioning. The researchers suggest that future research explores this issue, especially amongst non-student adults.

Another limitation was the nature of the locus of control instrument the researchers used. Despite adequate internal consistency and significant correlative empirical results with career thinking and sense of coherence, locus of control showed weak predictive relationships with negative career thoughts and career decision-making self-efficacy. The researchers argued that the results could be a consequence of the age (40 years) of the Rotter I-E LOCS scale, its ipsative nature and the scant normative reliability and validity data (see Lefcourt, 1991).

The researchers suggest that future research investigates the inclusion of new, yet reliable and valid, locus of control 
instruments. A South African option is the Locus of Control Questionnaire (Schepers, 1995). The researchers suggest that researchers repeat this study in South Africa using a comparative study.

\section{Author acknowledgements}

\section{Authors' competing interests}

The authors declare that they have no financial or personal relationship(s) that may have inappropriately influenced them in writing this paper.

\section{Authors' contributions}

Kirk Austin was the project leader. He planned and executed the empirical study. Frans Cilliers played a supervisory role and edited the manuscript academically.

\section{References}

Amundson, N., \& Borgan, W. (1996). At the controls: Charting your course through unemployment. Scarborough: Nelson Canada.

Antonovsky, A. (1998). The structure and properties of the Sense of Coherence scale. In H.I. McCubbin, E.A. Thompson, A.I. Thompson \& J.E. Fromer (Eds.), Stress, Coping, and Health in Families (pp. 21-41). Thousand Oaks, CA: Sage.

Antonovsky, A. (1993). The structure and properties of the Sense of Coherence scale. Social Science and Medicine, 36(6), 725-733. http://dx.doi.org/10.1016/0277 9536(93)90033-Z

Antonovsky, A. (1987). Unravelling the mystery of health: How people manage stress and stay well. San Francisco, CA: Jossey Bass.

Antonovsky, A. (1979). Health stress and coping. San Francisco, CA: Jossey Bass.

Austin, R.K. (2005). The relationship between career thinking and salutogenic functioning. Unpublished doctoral dissertation. University of South Africa, Pretoria, South Africa.

Austin, R.K., Dahl, A.D., \& Wagner, B.D. (2010). The Roles of Negative Career Thinking $\&$ Sense of Coherence in Predicting Career Decision Status. The Canadian Journal of Counseling, 44(1), 1-24.

Austin, R.K., Wagner, B., \& Dahl, D. (2004). Reducing career indecisiveness in adults. International Journal of Disability Community and Rehabilitation, 3(2). Retrieved n.d., from http://www.ijdcr.ca/VOL03 02 CAN/articles/austin.shtml

Austin, R.K., Wagner, B., \& Dahl, D. (2003). Reducing negative career thoughts in adults, International Journal of Disability Community and Rehabilitation, 2(2). Retrieved n.d., from http://www.ijdcr.ca/VOL02 02 CAN/articles/austin.shtml.

Auxier, J.W. (1994). A prelude to matching: Locus of control and belief in divine intervention among members of alcoholics anonymous and rational recovery. Unpublished doctoral dissertation, University of Arizona, Tuscon, AZ.

Babbie, E. (2001).The practice of social research. (9th edn). Belmont, TN: Wadsworth/ Thomson Learning.

Bandura, A. (2000). Exercise of human agency through collective efficacy. Current Directions in Psychological Science, 9, 75-78. http://dx.doi.org/10.1111/14678721.00064

Bandura, A. (1999). Social cognitive theory of personality. In L. Pervin \& O. John (Eds.) Handbook of personality, (2nd edn., pp.154-196). New York: Guildford Press.

Bandura, A. (1997). Self-efficacy: The exercise of control. New York: W.H. Freeman and Company.

Bergeron, L.M., \& Romano, J.L. (1994). The relationships among career decisionmaking, self-efficacy, educational indecision, vocational indecision, and gender. Journal of College Student Development, 35(1), 19-24.

Betz, N.E. (2004). Contributions of self-efficacy theory to career counselling: A personal perspective. The Career Development Quarterly, 52, 340-353.

Betz, N.E., Klein, K.L., \& Taylor, K.M. (1996). Evaluation of the short form of the Career Decision-making Self-efficacy Scale. Journal of Career Assessment, 4(1), 47-58. http://dx.doi.org/10.1177/106907279600400103

Betz, N.E., \& Luzzo, D.A. (1996). Career assessment and the Career Decision-making Self-efficacy Scale. Journal of Career Assessment, 4(4), 413-428. http://dx.doi. org/10.1177/106907279600400405

Betz, N.E., \& Taylor, K.M. (1994). Manual for the Career Decision-making Self-efficacy Scale. Columbus: Department of Psychology, The Ohio State University.

Bobak, M., Pikhart, H., Hertzman, C., Rose, R., \& Marmot, M. (1998). Socioeconomic factors, perceived control, and self reported health in Russia: A cross sectional survey. Social Science and Medicine, 47, 269-279. http://dx.doi.org/10.1016/ S0277-9536(98)00095-1

Breverton, P., \& Millward, L. (2004). Organisational research methods. A guide for students and researchers. London, UK: Sage.
Brown, C., Reedy, D., Fountain, J., Johnson, A., \& Dichiser, T. (2000). Battered women's career decision-making self-efficacy: Further insights and contributing factors. Journal of Career Assessment, 8(3), 251-265. http://dx.doi. factors. Journal of Career Ass
org/10.1177/106907270000800304

Carr, D. (2004). The effect of a workbook intervention on college student's reframes of dysfunctional career thoughts: technical report 37. Florida State University, Cente for the Study of Technology in Counseling and Career Development retrieved for the Study of Technology in Counseling and Career Development, retrieved n.d., from http://career.fsu.edu/documents/Tect
Report\%2037/Technical\%20Report\%2037.htm

Chamberlain, K., Petrie, K., \& Azriah, R. (1992). The role of optimism and sense of coherence in predicting recovery following surgery. Psychology and Health, 7 301-310. http://dx.doi.org/10.1080/08870449208403159

Cilliers, F. (2003). Burnout and salutogenic functioning of nurses. Curationis, 26(1), $62-74$.

Cilliers, F. (2002). Salutogenic coping with burnout among nurses: A qualitative study. South African Journal of Labour Relations, 26(4), 61-85.

Cilliers, F., \& Kossuth, S.P. (2004). The reliability and factor structure of three measures of salutogenic functioning. South African of Labour Relations, 28(2), 59-76.

Cohen, J. (1992). A power primer. Psychological Bulletin, 112(1), 155-159. http:// dx.doi.org/10.1037/0033-2909.112.1.155, PMid:19565683

Costa Jr, P.T., \& McCrae, R.R. (1992). Revised NEO Personality Inventory. Odessa: Psychological Assessment Resources, Inc.

Dahl, D. (2010). The relationship between cognitive ability, emotional intelligence and negative career thoughts: A study of career-exploring adults. Unpublished doctoral dissertation. University of South Africa, Pretoria, South Africa.

Dahl, D., Austin, R.K., \& Wagner, B. (2010). Negative Career Thoughts through Adulthood. Career Planning \& Adult Development Journal, 25(4), 183-187.

Dahl, A.D., Austin, R.K., Wagner, B.D., \& Lukas, A. (2008). The Relationship between Negative Career Thoughts \& Emotional Intelligence. The Canadian Journal of Career Development, 7(1), 4-10.

De Brabander, B., Hellemans, J., \& Boone, C. (1999). Selection pressures induce a shift towards more internal scores on Rotter's I-E Locus of Control Scale. Current Research in Social Psychology (CRISP), 4(1). Retrieved n.d., from http://www. Research in Social Psychology (CRISP),
uiowa.edu/ $\sim$ grpproc/crisp/crisp.4.1.htm

Desruisseaux, P. (1998, 04 December). US trails 22 nations in high school completion. The Chronicle of Higher Education, A45.

Diraz, T., Ortlepp, K., \& Greyling, M. (2003). The relationship between inter-role conflict, life satisfaction and sense of coherence in a sample of working mothers. South African Journal of Psychology, 33(3), 191-194.

Edwards, D., \& Besseling, E. (2001). Relationship between depression, anxiety, sense of coherence, social support and religious involvement in a small rural community affected by industrial relations conflict. South African Journal of Psychology, 31(4), 62-71.

Feather, N.T. (1997). Economic deprivation and the psychological impact of unemployment. Australian Psychologist, 32, 37-45. http://dx.doi. org/10.1080/00050069708259616

Felton, E.S. (1996). Social support, self-efficacy, and sense of coherence in African American, Asian and white college students. Unpublished doctoral dissertation, American, Asian and white college
Georgia State University, Atlanta.

Flannery, R.B., Perry, J.C., Penk, W.E., \& Flannery, G.J. (1994). Validating Antonovsky's Sense of Coherence Scale. Journal of Clinical Psychology, 50(4), 575-577. http:// dx.doi.org/10.1002/1097-4679(199407)50:4<575::AID-JCLP2270500412> 3.0.CO;2-8

Fournier, G., \& Jeanrie, C. (2003). Locus of control: Back to the basics. In S.J. Lopez \& C.R. Snyder (Eds.), Positive psychological assessment: A handbook of models and measures, (pp.139-154). Washington, DC: American Psychological Association.

Fournier, G., Jeanrie, C., \& Drapeau, S. (1996). Échelle de Locus de contrôle relié à la carrière [Vocational Locus of Control Scale]. Quebec: University of Laval. http:// dx.doi.org/10.1037/10612-009

Frenz, A.W. (1990). Measuring Antonovsky's sense of coherence construct: A psychometric study (Doctoral dissertation, 1990). Dissertation Abstracts International, 51, 6141 .

Frenz, A., Carey, M., \& Jorgenson, R. (1993). Psychometric evaluation of Antonovsky's Sense of Coherence Scale. Psychological Assessment, 5, 145-153. http://dx.doi. org/10.1037/1040-3590.5.2.145

Friedman, R., Schwartz, J.E., Schnall, P.L., Landsbergis, P.A., Pieper, C., Gerin, W., \& Pickering, T.G. (2001). Psychological variables in hypertension: Relationship to casual or ambulatory blood pressure in men. Psychosomatic Medicine, 63, 19-31.

Fuqua, D.R., Blum, D.R., \& Hartman, B.W. (1988). Empirical support for the differential diagnosis of career indecision. The Career Development Quarterly, 36, 364-373.

Gordon, V.N. (1998). Career decidedness types: A literature review. The Career Development Quarterly, 46(4), 386-403.

Grob, A., Little, T.D., Wanner, B., Wearing, W., \& Euronet (1996). Adolescent's well being and perceived control across 14 sociocultural contexts. Journal of Personality and Social Psychology, 71, 785-795. http://dx.doi.org/10.1037/0022-3514.71.4.785, PMid:8888603

Hack, T.F., \& Degner, L.F. (2004). Coping responses following breast cancer diagnosis predict psychological adjustment three years later. Psycho-Oncology, 13(4), 235247. http://dx.doi.org/10.1002/pon.739, PMid:15054728

Hanish, K.A. (1999). Job loss and unemployment research from 1994 to 1998: A review and recommendations for research and intervention. Journal of Vocationa Behavior, 55, 188-220. http://dx.doi.org/10.1006/jvbe.1999.1722

Harris, D.L. (1997). The sense of coherence factor as a predictor of pharmacy schoo grade point average. Unpublished doctoral dissertation. University of Maryland College Park, MD. 
Hart, K.E., Hittner, J., \& Paras, K.C. (1991). Sense of coherence, trait anxiety and the perceived availability of social support. Journal of Research in Personality, 25, perceived availability of social support. Journal of Research

Hedov, G., Annernen, G., \& Wikblad, K. (2002). Swedish parents of children with Down's syndrome: Parental stress and sense of coherence in relation to employment rate and time spent in child care. Scandinavian Journal of Caring Sciences, 16(4), 424-430. http://dx.doi.org/10.1046/j.1471-6712.2002.00109.x PMid:12445113

Hintermair, M. (2004). Sense of coherence: A relevant resource in the coping process of mothers of deaf and hard of hearing children? Journal of Deaf Studies \& Deaf Education, 9(1), 15-26. http://dx.doi.org/10.1093/deafed/enh005, PMid:15304399

Höge, T., \& Büssing, A. (2004). The impact sense of coherence and negative affectivity on the work stressor-strain relationship. Journal of Occupational Health Psychology, 9(3), 195-205.

Holland, J.L., Daiger, D.C., \& Power, G. (1980). Some diagnostic scales for research in decision-making and personality: Identity, information, and barriers. Journal of Personality and Social Psychology, 39, 1191-1200. http://dx.doi.org/10.1037/ h0077731

Johnson, M. (2004). Approaching the salutogenesis of sense of coherence: The role of 'active' self esteem and coping. British Journal of Health Psychology, 9, 419-432. $\mathrm{http}: / / d x . d o i . o r g / 10.1348 / 1359107041557057$, PMid:15296687

Jones, L.K. (1989). Measuring a three-dimensional construct of career indecision among college students: A revision of the vocational decision scale - The Career Decision Profile. Journal of Counselling Psychology, 36, 477-486. http://dx.doi. org/10.1037/0022-0167.36.4.477

Joseph, L.M., \& Greenberg, M.A. (2001). The effects of a career transition program on reemployment success in laid off professionals. Consulting Psychology Journal: Practice and Research, 53(3), 169-181. http://dx.doi.org/10.1037/1061 4087.53.3.169

Judge, T.A., \& Locke, E.A. (1993). Effect of dysfunctional thought processes on subjective well being and job satisfaction. Journal of Applied Psychology, 78, 475subjective well being and job satisfaction. Journal of $A p p$
490. http://dx.doi.org/10.1037/0021-9010.78.3.475

Judge, T.A., Thoresen, C.J., Pucik, V., \& Welbourne, T.M. (1999). Managerial Coping with organisational change: A dispositional perspective. Journal of Applied Psychology, 84(1), 107-122. http://dx.doi.org/10.1037/0021-9010.84.1.107

Kalimo, R., Pahkin, K., \& Mutanen, P. (2002). Work and personal resources as longterm predictors of well-being. Stress \& health: Journal of the international society for the investigation of stress, 18(5), 227-234.

Kalimo, R., \& Vuori, J. (1990). Work and sense of coherence: Resources for competence and life satisfaction. Behavioral Medicine, 16(2), 76-89. http://dx.doi.org/10.108 0/08964289.1990.9934595, PMid:2364180

Karlson, B., Seger, L., Osterberg, K., Gunnel, A., \& Orbaek, P. (2000). Stress management in men with solvent-induced chronic toxic encephalopathy. Journal of Occupational and Environmental Medicine, 42(6), 670-675. http://dx.doi. org/10.1097/00043764-200006000-00019

Keim, J., Strauser, D.R., \& Ketz, K. (2002). Examining the differences in career thoughts of women in three low socioeconomic status groups. Journal of Employment Counseling, 39(1), 31-42.

Kerpelman, J.L., \& Mosher, L.S. (2004). Rural African American adolescents future orientation: The importance of self-efficacy, control and responsibility and identity development. Identity: An International Journal of Theory and Research, $4(2), 187-208$

Kilk, K.L. (1997). The relationship between dysfunctional career thoughts and choosing an academic major. Doctoral dissertation, Colorado State University, 1997. Dissertation Abstracts International, 58 (08A), 3038.

Kivimaeki, M., Elovainio, M., \& Vahtera, J. (2002). Sense of coherence as a mediato between hostility and health: Seven-year prospective study on female employees. Journal of Psychosomatic Research, 52(4), 239-247. http://dx.doi.org/10.1016/ S0022-3999(01)00305-1

Kleiman, T., Gati, I., Peterson, G., Sampson, J., Reardon, R., \& Lenz, J. (2004) Dysfunctional thinking and difficulties in career decision making. Journal of Caree Assessment, 12, 312-331. http://dx.doi.org/10.1177/1069072704266673

Korotkov, D. (1998). Sense of coherence: making sense out of chaos. In T.P. Wong \& P.S. Fry (Eds.), The human quest for meaning, (pp. 51-70). Mahwah, NJ: Lawrence Erlbaum Associates.

Larson, L.M., Piersel, W.C., Imao, R.A.K., \& Allen, S.J. (1990). Significant predictor of problem solving appraisal. Journal of Counseling Psychology, 37(4), 482-490. $\mathrm{http}: / / \mathrm{dx}$.doi.org/10.1037/0022-0167.37.4.482

Latiff, D.A. (2000). The relationship between pharmacy students locus of control, Machiavellianism, and moral reasoning. American Journal of Pharmaceutical Education, 64, 33-37.

Lefcourt, H.M. (1991). Locus of control. In J.P Robinson, P.R. Shaver \& L.S. Wrightman (Eds.), Measurement of personality and social psychological attitudes, (pp. 413499). New York: Academic Press.

Lent, R.W., Hackett, G., \& Brown, S.D. (2000). Contextual supports and barriers to career choice: A social cognitive analysis. Journal of Counseling Psychology, 47 36-49. http://dx.doi.org/10.1037/0022-0167.47.1.36

Levenson, H. (1981). Differentiating among internality, powerful others and chance. In H.M. Lefcourt (Ed.), Research with the locus of control construct, Vol. 1 Assessment methods, (pp. 15-63). New York: Academic Press.

Litt, M.D. (1988). Self-efficacy and perceived control: Cognitive mediators of pain tolerance. Journal of Personality and Social Psychology, 4, 149-160. http://dx.doi. org/10.1037/0022-3514.54.1.149, PMid:3346804
Lustig, D.C., \& Strauser, D.R. (2002). The relationship between sense of coherence and career thoughts. Career Development Quarterly, 51, 2-11.

Lustig, D., \& Strauser, D. (2008). The impact of sense of coherence on career thoughts for individuals with disabilities. Rehabilitation Counseling Bulletin, 51(3), 139147. http://dx.doi.org/10.1177/0034355207311313

Luzzo, D.A. (1993). Reliability and validity testing of the Career Decision-making Selfefficacy Scale. Measurement and Evaluation in Counseling and Development, 26 137-142.

Luzzo, D.A. (1995). The relative contributions of self-efficacy and locus of control to the prediction of career maturity. Journal of College Student Development, 36(1), 61-66.

Luzzo, D.A. (1996). A psychometric evaluation of the Career Decision-making SelfEfficacy Scale. Journal of Counseling and Development, 74, 276-279.

Luzzo, D.A., Funk, D.P., \& Strang, J. (1996). Attributional retraining increases career decision-making self-efficacy. Career Development Quarterly, 44(4), 378-386.

Mau, W. (2003). Factors that influence persistence in science and engineering career aspirations. The Career Development Quarterly, 51, 234-243.

McSherry, W.C., \& Holm, J.E. (1994). Sense of coherence: Its effect on psychological and physiological processes prior to during and after a stressful situation. Journal of Clinical Psychology, 5, 476-487. http://dx.doi.org/10.1002/10974679(199407)50:4<476::AID-JCLP2270500402>3.0.CO;2-9

McWhirtner, E.H., Rasheed, S., \& Crothers, M. (2000). Effects of high school career education on social cognitive variables. Journal of Counseling Psychology, 47(3) 330-341.

Morrison, T.G., O'Connor, W.E., \& Morrison, M.A. (2001). Determinants of psychological well-being among unemployed women and men. Psychology \& Education: An Interdisciplinary Journal, 38(1), 34-41.

Muchinsky, P. (2006). Psychology applied to work. (8th edn.). Belmont, TN: ThomsonWadsworth.

Neault, R.A. (2002, June). Beyond the basics: Real world career management. Paper presented at the National Consultation on Career Development, Ottawa, Canada.

Ochs, L.A., \& Roessler, R.T. (2004). Predictors of career exploration intentions: A social cognitive career theory perspective. Rehabilitation Counselling Bulletin, 47(4), 224-233. http://dx.doi.org/10.1177/00343552040470040401

Osberg, L., Wien F., \& Grude, J. (1995). Vanishing jobs: Canada's changing workplace. Toronto: James Lorimer \& Company.

Osborn, D.S. (1998). The relationships among perfectionism, dysfunctional career thoughts, and career indecision. Doctoral dissertation, Florida State University, 1998. Dissertation Abstracts International, 59(10), 3746A

Osipow, S. (1999). Assessing career indecision. Journal of Vocational Behavior, 55(3), 147-154. http://dx.doi.org/10.1006/jvbe.1999.1704

Osipow, S.H., Carney, C.G., Winer, J., Yanico, B., \& Koschier, M. (1976). The Career Decision Scale. (3rd revision). Columbus: Marathon Consulting and Press.

Osipow, S.H., \& Reed, R. (1985). Decision-making style and career indecision in college students. Journal of Vocational Behavior, 27(3), 368-373. http://dx.doi. org/10.1016/0001-8791(85)90043-0

Paa, H.K., \& McWhirter, E.H. (2000). Perceived influences on high school students' current career expectations. Career Development Quarterly, 49, 29-44.

Pallant, J.F., \& Lae, L. (2002). Sense of coherence, well being, coping and personality factors: Further evaluation of the sense of coherence scale. Personality \& Individud Differences, 33(1), 39-48. http://dx.doi.org/10.1016/S0191-8869(01)00134-9

Patrick, A., \& Durndell, A. (2004). Lucid dreaming and personality: A replication. Dreaming, 14(4), 234-239. http://dx.doi.org/10.1037/1053-0797.14.4.234

Patton, W., \& Creed, P.A. (2001). Developmental issues in career maturity and career decision status. Career Development Quarterly, 49, 336-351.

Paulsen, A.M. \& Betz, N.E. (2004). Basic confidence predictors of career decision making self-efficacy. The Career Development Quarterly, 52, 354-362.

Peterson, N., \& González, R.C. (2005). The role of work in people's lives. (2nd edn.) Belmont, TN: Wadsworth/Thomson Learning.

Perry, R.P. (2003). Perceived (academic) control and causal thinking in achievement settings. Canadian Psychology, 44(4), 312-331. http://dx.doi.org/10.1037/ h0086956

Perry, R.P., Hladkyj, S., Pekrun, R.H., \& Pelletier, S. (2001). Academic control and action control in the achievement of college students: A longitudinal study. Journa of Educational Psychology, 93(4), 776-789. http://dx.doi.org/10.1037/0022 0663.93.4.776

Quimby, J.L., \& O'Brien, K.M. (2004). Predictors of student and career decision-making self-efficacy among non-traditional college women. The Career Development Quarterly, 52, 323-339.

Rachman, S. (1990). Learned resourcefulness in the performance of hazardous tasks. In M. Rosenbaum (Ed.), Learned resourcefulness: On coping skills, self control and adaptive behaviour, (pp. 165-181). New York: Springer.

Reed, C.A., Lenz, J.G., Reardon, R.C., \& Leierer, S.J. (2000). Reducing negative career thoughts with a career course: Technical report No. 25. Florida State University Center for the Study of Technology in Counseling and Career Development retrieved n.d., from http://www.career.fsu.edu/techcenter//TR-25.html

Rothman, S., \& Agathagelou, A.M. (2000). Die verband tussen lokus van beheer en werkstevredenheid by senior polisiepersoneel [The relationship between locus of control and work satisfaction amongst senior police staff]. Tydskrif vir Bedryfsielkunde, 26(2), 20-26.

Rothman, S., \& Van Rensberg, P. (2002). Psychological strengths, coping and suicide ideation in South African police services in the northwest province. South African Journal of Industrial Psychology, 28(3), 39-49. 
Rothmann, S., \& Coetzee, S. (2003, May) Dispositional characteristics, quality work life and effectiveness of members of self-managed work teams. Poster presented at the 11th European Congress of Work and Organisational Psychology, Lisbon, at the 11 .

Rotter, J.B. (1966). Generalised expectancies for internal versus external control of reinforcement. Psychological Monographs, 8. (1, Whole \# 609).

Rumbaut, R.G., Anderson, J.P., \& Kaplan, R.M. (1983). Stress, health and the sense of coherence. In M.J. Magenheim (Ed.), Geriatric Medicine and the Social Sciences, (85-93). Philadelphia, PA: Saunders.

Ryland, E., \& Greenfeld, S. (1991). Work stress and well being: An investigation of Antonovsky's sense of coherence model. Journal of Behavior and Personality $6(7), 39-54$.

Sampson, J.P., Jr., Peterson, G.W., Lenz, J.G., Reardon, R.C., \& Saunders, D.E. (1996a) Career Thoughts Inventory. Odessa: Psychological Assessment Resources.

Sampson, J.P., Peterson, G.W., Lenz, J.G., Reardon, R.C., \& Saunders, D.E. (1996b) Career Thoughts Inventory professional manual. Odessa: Psychological Assessment Resources.

Sampson, J.P., Jr., Peterson, G.W., Lenz, J.G., Reardon, R.C., \& Saunders, D.E. (1999). The use and development of the Career Thoughts Inventory. Florida State University, Center for the Study of Technology in Counseling and Career Development retrieved n.d., from http://www.aus.fsu.edu/techcntr/ctiwww.htm

Sampson, J., Reardon, R.C., Peterson, G.W., \& Lenz, J.G. (2004). Career counselling \& services: A cognitive information processing approach. Belmont, TN: Brooks/Cole.

Saunders, D.E., Peterson, G.W., Sampson, J.P., Jr., \& Reardon, R.C. (2000). The relation of depression and dysfunctional career thinking to career indecision. Journal of Vocational Behavior, 56, 288-298. http://dx.doi.org/10.1006/jvbe.1999.1715

Savickas, M.L. (1994). Measuring career development: Current status and future directions. The Career Development Quarterly, 43 (1), 54-62.

Savickas, M.L. (2001, March 07). The future of career in psychology: Recovering lost meaning. Symposium Presentation at the International Association for Educational and Vocational Guidance, Vancouver, Canada.

Schepers, J.M. (1995). Die lokus van beheer vraelys: Konstruksie en evaluering van 'n meetinstrument [The locus of control questionnaire: Construction and evaluation of a measuring instrument]. Johannesburg: RAU.

Sharf, R.F. (2006). Applying career development theory to counselling. (4th edn.) Belmont, TN: Brooks/Cole.

Skinner, E.A. (1996). A guide to constructs of control. Journal of Personality and Socia Psychology, 71(3). 549-570. http://dx.doi.org/10.1037/0022-3514.71.3.549, PMid:8831161

Snyder, C.R., \& Lopez, S.J. (2009). Oxford handbook of positive psychology. New York: Oxford University Press.

Starrin, B., Jönsson, B., \& Rantakeisu, U. (2001). Sense of coherence during unemployment. International Journal of Social Welfare, 1, 107-116. http://dx.doi. org/10.1111/1468-2397.00160

Spector, P.E. (1988). Development of the Work Locus of Control scale. Journal of Occupational Psychology, 61, 335-340.

Snyder, C.R., \& Lopez, S.J. (2009). Oxford handbook of positive psychology. New York: Oxford University Press.

Strauser, D.R., Lustig, D.C., Keim, J., Ketz, K., \& Malesky, A. (2002). Analyzing the differences in career thoughts based on disability status - Differences in Caree Thoughts. Journal of Rehabilitation, 68(1), 27-32.

Strümpfer, D.J.W. (1990). Salutogenesis: A new paradigm. South African Journal of Psychology, 20 (4), 265-276.

Strümpfer, D.J.W. (1995). The origins of health and strength: From 'salutogenesis' to 'fortigenesis'. South African Journal of Psychology, 25(2), 81-89.
Super, D.E. (1983). Assessment in career guidance: Toward a truly developmental counselling. The Personnel and Guidance Journal, May, 555-562.

Super, D.E. (1990). A life span, life space approach to career development. In D. Brown \& L. Brooks (Eds.), Career choice and development: Applying contemporary theories to practice, (pp. 197-261). San Francisco, CA: Jossey Bass.

Super, D.E., Savickas, M.L., \& Super, C.M. (1996). The life span, life-space approach to careers. In D. Brown \& L. Brooks, \& Associates (Eds.), Career choice and development. (3rd edn., pp. 121-178). San Francisco: Jossey Bass.

Taylor, K.M. (1982). An investigation of vocational indecision in college students: Correlates and moderators. Journal of Vocational Behavior, 21 (3), 318-329. http://dx.doi.org/10.1016/0001-8791(82)90040-9

Taylor, K.M., \& Betz, N. (1983). Applications of self-efficacy theory to the understanding and treatment of career indecision. Journal of Vocational Behavior, 22, 63-81. $\mathrm{http}: / / \mathrm{dx}$.doi.org/10.1016/0001-8791(83)90006-4

Taylor, K.M., \& Popma, J. (1990). An examination of the relationships among career decision-making self-efficacy, career salience, locus of control, and vocational indecision Journal of Vocational Behavior, 37, 17-31 http://dx.doi. org/10.1016/0001-8791(90)90004-L

Terre Blanche, M., Durrheim, K., \& Painter, D. (2006). Research in practice. Applied methods for the social sciences. Cape Town: UCT Press.

Thompson, S. (2002). The role of personal control in adaptive functioning. In S.J. Lopez \& C.R. Snyder (Eds.), The handbook of positive psychological assessment, (pp. 202-213). Washington, DC: American Psychological Association.

Turner, N., Barling, J., \& Zacharatos, A. (2002). Positive psychology at work. In S.J. Lopez \& C.R. Snyder (Eds.), The handbook of positive psychological assessment, (pp. 715-728). Washington, DC: American Psychological Association.

Van Den Broek, H., Vanderheyden, K., \& Cools, E. (2003). Individual differences in cognitive styles. Development, validation and cross validation of the Cognitive Styles Inventory. Vlerick Leuven Gent Management Schools Working Paper Series. Retrieved n.d., from http://www.vlerick.be/research/workingpapers/vlgmswp-2003-27.pdf

Van der Colff, J.J., \& Rothmann, S. (2009). Occupational stress, sense of coherence, coping, burnout and work engagement of registered nurses in South Africa. SA Journal of Industrial Psychology, 35(1), 1-10.

Van Der Merwe, P., \& Greeff, A.P (2003).Coping mechanisms of unemployed African men with dependents. American Journal of Family Therapy, 31(2), 91-105. http:// dx.doi.org/10.1080/01926180301127

Vinokur, A.D., \& Schul, Y. (2002). The web of coping resources and pathways to reemployment following a job loss. Journal of Occupational Health Psychology, 7(1), 68-83. http://dx.doi.org/10.1037/1076-8998.7.1.68, PMid:11827235

Wanberg, C.R. (1997). Antecedents and outcomes of coping behaviors among unemployed and reemployed individuals. Journal of Applied Psychology, 82(5), 731-744. http://dx.doi.org/10.1037/0021-9010.82.5.731, PMid:9337607

Waters, L.E., \& Moore, K.A. (2002). Self-esteem, appraisal and coping: A comparison of unemployed and re-employed people. Journal of Organisational Behavior, 23(5), 593-604. http://dx.doi.org/10.1002/job.156

Weinstein, F.M., Healy, C.C., \& Ender, P.B. (2002). Career choice anxiety, coping and perceived control. Career Development Quarterly, 50(4), 339-350.

Williamson, E.G. (1937). Scholastic motivation and the choice of a vocation. Schoo and Society, 46, 353-357.

Wooten, H.R. (1993). The "Indecisive disposition" and the college student athlete. TCA Journal, Fall, 54-59.

Wright, L.K. (2001). The effects of self-efficacy, interest, and dysfunctional thoughts on level of career decidedness, and satisfaction with occupational choice. Doctoral dissertation, Florida State University, 2001. Dissertation Abstracts International, 61(7B), 3889. 